\title{
ANALISIS KEJADIAN TUBERKULOSIS PARU DAN FAKTOR RISIKONYA DI KECAMATAN PAMULANG, KOTA TANGERANG SELATAN
}

\author{
Fenita Purnama, Ita La Tho \\ Sekolah Tinggi Ilmu Kesehatan Kharisma Persada \\ Tangerang Selatan, 15417 \\ E-mail: fenita.purnama@masda.ac.id
}

\begin{abstract}
ABSTRAK
Tuberkulosis Paru merupakan permasalahan kesehatan global yang telah menjadi perhatian dunia selama dua dekade terakhir. Menurut Kementerian Kesehatan RI tahun 2016, Provinsi Banten memiliki jumlah penderita tuberkulosis paru yang diperkirakan mencapai 40.227 orang, namun sudah terdeteksi atau yang terdata berjumlah sebanyak 16.608 orang, dengan peningkatan pertama jumlah penderita berada di Tangerang Selatan mencapai 2.089 orang. Di Kota Tangerang Selatan tahun 2015 ditemukan sebanyak 5.246 suspek TB Paru, dimana 735 kasus diantaranya merupakan kasus TB Paru BTA Positif. Tujuan penelitian ini untuk mengidentifikasi faktor-faktor yang berhubungan dengan kejadian tuberculosis paru di Kecamatan Pamulang, Kota Tangerang Selatan. Penelitian ini merupakan penelitian kuantitatif, menggunakan metode penelitian survei analitik dengan pendekatan cross sectional. Jumlah sampel yang didapat sebanyak 210 responden. Sebab penelitian ini menggunakan metode Rapid Survey (Survei Cepat) dengan kriteria sampel sebanyak 210 sampai 300 responden. Hasil penelitian ini menunjukkan bahwa tidak ada hubungan yang bermakna antara pengetahuan tentang tuberkulosis paru dengan kejadian tuberkulosis paru pada responden ( $\mathrm{p}$ value = $0.23>0,05$ ) dan ada hubungan yang bermakna antara sikap dengan kejadian tuberkulosis paru ( $\mathrm{p}$ value $=0,000$ $<0,05)$, dengan OR sebesar 3,237. Artinya, sikap mengenai pencegahan tuberkulosis paru yang kurang baik akan meningkatkan risiko terjadinya kejadian tuberkulosis paru sebesar 3x lipat dibandingkan dengan sikap mengenai pencegahan tuberkulosis paru yang baik.
\end{abstract}

Kata Kunci : Tuberkulosis Paru, Sikap Mengenai Pencegahan Tuberkulosis Paru, Rapid Survey

\begin{abstract}
Pulmonary tuberculosis is a global health problem that has been a global concern for the past two decades. According to the Indonesian Ministry of Health in 2016, Banten Province has an estimated number of lung patients with tuberculosis reaching 40,227 people, but has been detected or recorded as many as 16,608 people, with the first increase in the number of sufferers in South Tangerang reaching 2,089 people. In the City of South Tangerang in 2015 there were 5,246 suspected TB pulmonary cases, of which 735 cases were positive smear pulmonary TB cases. The purpose of this study was to identify factors associated with the incidence of pulmonary tuberculosis in Pamulang Subdistrict, South Tangerang City. This research is a quantitative study, using analytic survey research methods with cross sectional approach. The number of samples obtained was 210 respondents. Because this research uses the Rapid Survey method with sample criteria of 210 to 300 respondents. The results of this study indicate that there is no significant relationship between knowledge about pulmonary tuberculosis with the incidence of pulmonary tuberculosis in respondents ( $p$ value $=0.23>0.05$ ) and there is a significant relationship between attitude and the incidence of pulmonary tuberculosis ( $p$ value $=0,000<0$, 05), with an OR of 3.237. That is, the attitude about the prevention of pulmonary tuberculosis that is not good will increase the risk of the occurrence of pulmonary tuberculosis by $3 x$ compared with the attitude regarding the prevention of pulmonary tuberculosis is good. Keywords: Lung Tuberculosis, Attitudes Regarding Prevention of Lung Tuberculosis, Rapid Survey
\end{abstract}




\section{PENDAHULUAN}

Tuberkulosis Paru merupakan permasalahan kesehatan global yang telah menjadi perhatian dunia selama dua dekade terakhir (WHO, 2015). Sepertiga dari populasi dunia sudah tertular dengan tuberkulosis paru, tuberkulosis paru lebih banyak menyerang laki-laki (60\%) daripada perempuan (40\%). Proporsi kasus tuberkulosis paru terbanyak ditemukan pada kelompok usia produktif (25-34 tahun), yaitu sebesar 18,07\%, diikuti kelompok umur 45-54 tahun sebesar $17,25 \%$. Kasus tuberkulosis paru juga paling banyak ditemukan pada golongan penduduk yang tidak bekerja dan yang tidak sekolah dan jumlah kasus di perkotaan lebih tinggi daripada di pedesaan. Hal ini menyebabkan kesehatan yang buruk diantara jutaan orang setiap tahun dan menjadi penyebab utama kedua kematian penyakit menular di seluruh dunia setelah Human Immunodeficiency Virus (HIV)/AIDS.

Pada tahun 2014, tuberkulosis paru telah membunuh 1,5 juta orang. WHO memperkirakan terdapat 9,6 juta kasus tuberkulosis paru pada tahun 2014 namun hanya 6 juta kasus tuberkulosis paru yang terlaporkan, artinya terdapat 3,6 juta kasus tuberkulosis paru yang tidak terdiagnosa atau tidak terlaporkan. Sementara itu 58\% kasus tuberkulosis paru dunia diantaranya terdapat di Asia Tenggara dan Pasifik Barat (WHO, 2015). Berdasarkan data World Health Organization (WHO), jumlah kasus baru tuberkulosis paru pada 2015 mencapai 10,4 juta jiwa meningkat dari sebelumnya hanya 9,6 juta.

$$
\text { Adapun jumlah temuan }
$$

tuberkulosis paru terbesar adalah di India sebanyak 2,8 kasus, diikuti Indonesia sebanyak 1,02 juta kasus dan Tiongkok sebanyak 918 ribu kasus. Kemudian, disusul oleh Filipina, Pakistan, Nigeria, dan Afrika selatan.

Dalam laporan yang bertajuk Global Tuberculosis Report 2016 itu, angka kematian akibat tuberkulosis paru di Indonesia mencapai 274 kasus perhari atau 100 ribu jiwa dalam setahun ditambah 26 ribu penderita tuberkulosis paru yang terindikasi HIV positif. Sementara angka kematian dunia yang diakibatkan oleh bakteri mycobacterium tuberculosa ini mencapai 1,4 juta jiwa ditambah 390 ribu jiwa penderita yang positif terkena HIV. Sedangkan prevalensi penderita tuberkulosis paru di Indonesia pada 2015 sebesar 395 per 100 ribu populasi dengan angka kematian sebesar 40 per 100 ribu populasi. Tuberkulosis paru menular lewat udara dan telah membunuh banyak orang. 
Untuk itu WHO akan mengurangi jumlah kasus baru sampai 80\% mulai 2016 dan mengurangi kematian akibat tuberkulosis paru sampai 90\% hingga 2030.

Menurut Kementerian Kesehatan RI tahun 2016, Provinsi Banten memiliki jumlah penderita tuberkulosis paru yang diperkirakan mencapai 40.227 orang, namun sudah terdeteksi atau yang terdata berjumlah sebanyak 16.608 orang, dengan peningkatan pertama jumlah penderita berada di Tangerang Selatan mencapai 2.089 orang.

Di Kota Tangerang Selatan tahun 2015 ditemukan sebanyak 5.246 suspek TB Paru, dimana 735 kasus diantaranya merupakan kasus TB Paru BTA Positif. Menurut Dinas Kesehatan provinsi Banten, ada beberapa analisis penyebab missing case atau kasus yang belum

\section{METODE}

Pendekatan yang digunakan dalam penelitian ini adalah pendekatan cross sectional yaitu suatu penelitian untuk mempelajari dinamika korelasi antara faktor dan resiko dengan efek cara pendekatan, observasi atau pengumpulan data sekaligus pada satu saat itu juga. Pendekatan Cross-sectional yaitu suatu penelitian untuk mempelajari dinamika korelasi antara variabel bebas dan variabel terikat dengan cara pendekatan terdeteksi, karena masih banyak masyarakat yang belum menerima informasi tentang tuberkulosis paru secara benar, masih banyak suspek yang belum diagnosis tuberkulosis paru, sebagian besar layanan masyarakat kesehatan swasta belum melaporkan adanya kasus tuberkulosis paru, dan masih banyak layanan kesehatan swasta yang tidak memprakarsai strategi DOTs (Directly Observed Treatment Short-course) dalam tatalaksana TB Paru, serta kurangnya pengetahuan masyarakat untuk mencari layanyan tuberkulosis paru di Fasyankses (Fasiltas Layanan Kesehatan). DOTs merupakan strategi penanggulangan tuberkulosis paru di Rumah Sakit melalui pengobatan jangka pendek, dengan pengawasan langsung, karena DOTs adalah tempat untuk konsultasi pasien TB.

observasional atau pengumpulan data sekaligus pada suatu saat (point time approach). Artinya setiap subyek penelitian hanya diobservasi sekali saja.

Populasi penelitian ini adalah seluruh masyarakat di daerah Pamulang. Sampel yang digunakan pada penilitian ini adalah masyarakat di daerah Pamulang sebanyak 210 responden. Sebab penelitian ini menggunakan metode Rapid Survey (Survei Cepat) dengan kriteria sampel 
sebanyak 210 sampai dengan 300 responden.

Rapid Survey (survei cepat) merupakan salah satu metode survei yang dimaksudkan untuk memperoleh informasi tentang suatu masalah dalam jangka waktu yang relatif pendek, dengan biaya yang terjangkau dan hasil yang optimal (Iswandi, 2009). Hasil penelitian ini diolah dengan menggunakan epi info 7, sebuah program atau aplikasi pengolah data yang dicanangkan oleh WHO (World Health Organization).

\section{HASIL}

\section{Hasil Analisis Univariat}

\section{a. Pengetahuan tentang \\ tuberkulosis paru}

Berdasarkan

penelitian, didapatkan kategori

pengetahuan tentang tuberkulosis paru di Kecamatan Pamulang,

Kota Tangerang Selatan, dapat dilihat pada tabel 1 dibawah ini:

Tabel 1. Distribusi Frekuensi Pengetahuan tentang tuberkulosis paru di Kecamatan Pamulang Kota Tangerang Selatan

\begin{tabular}{lcc}
\hline $\begin{array}{c}\text { Pengetahuan tentang } \\
\text { rokok }\end{array}$ & Jumlah & Persentase (\%) \\
\hline Baik & 65 & 30,95 \\
\hline Kurang Baik & 145 & 69,05 \\
\hline Total & $\mathbf{2 1 0}$ & $\mathbf{1 0 0 , 0}$ \\
\hline
\end{tabular}

Berdasarkan tabel 1, dapat

diketahui bahwa responden

dengan pengetahuan terhadap penyakit tuberkulosis paru yang kurang baik sebanyak 145 orang $(69,05 \%)$.

\section{b. Sikap mengenai pencegahan}

\section{tuberkulosis paru}

Berdasarkan hasil penelitian, didapatkan kategori sikap mengenai pencegahan tuberkulosis paru di Kecamatan
Pamulang, Kota Tangerang Selatan, dapat dilihat pada tabel 2 sebagai berikut: 
Tabel 2. Distribusi Frekuensi Sikap mengenai pencegahan tuberkulosis paru di Kecamatan Pamulang, Kota Tangerang Selatan

\begin{tabular}{ccc}
\hline $\begin{array}{c}\text { Sikap mengenai } \\
\text { pencegahan } \\
\text { tuberkulosis paru }\end{array}$ & Jumlah & Persentase (\%) \\
\hline Baik & 131 & 62,38 \\
\hline Kurang Baik & 79 & 37,62 \\
\hline Total & $\mathbf{2 1 0}$ & $\mathbf{1 0 0 , 0}$ \\
\hline
\end{tabular}

Berdasarkan hasil tabel 2,

dapat diketahui bahwa sebanyak

79 responden $(37,62 \%)$ dari 210 responden memiliki sikap yang kurang baik mengenai pencegahan tuberkulosis paru.

\section{c. Kejadian Tuberkulosis Paru}

Berdasarkan hasil penelitian, didapatkan kategori Kejadian Tuberkulosis Paru di
Kecamatan Pamulang, Kota Tangerang Selatan, dapat dilihat pada tabel 3 dibawah ini:

Tabel 3. Distribusi Frekuensi Kejadian Tuberkulosis Paru di Kecamatan Pamulang, Kota Tangerang Selatan

\begin{tabular}{|c|c|c|}
\hline $\begin{array}{c}\text { Kejadian } \\
\text { Tuberkulosis Paru } \\
\end{array}$ & Jumlah & Persentase (\%) \\
\hline Tidak & 167 & 79,52 \\
\hline $\mathrm{Ya}$ & 43 & 20,48 \\
\hline Total & 210 & 100,0 \\
\hline
\end{tabular}

Berdasarkan tabel 3, dapat diketahui bahwa terdapat 43 responden ataupun keluarga responden pernah mengalami kejadian tuberkulosis paru sebanyak 43 orang $(20,48 \%)$. 


\section{Hasil Analisis Bivariat}

\section{a. Hubungan Pengetahuan}

\section{Tentang Tuberkulosis Paru}

dengan Kejadian Tuberkulosis

Paru

Berdasarkan uji statistik,

didapatkan hasil pada tabel

sebagai berikut :

Tabel 4. Hubungan Pengetahuan Tentang Tuberkulosis Paru dengan Kejadian Tuberkulosis Paru

\begin{tabular}{|c|c|c|c|c|c|c|c|}
\hline \multirow{3}{*}{$\begin{array}{c}\text { Pengetahuan } \\
\text { Tentang } \\
\text { Tuberkulosis Paru }\end{array}$} & \multicolumn{4}{|c|}{ Kejadian Tuberkulosis Paru } & \multirow{2}{*}{\multicolumn{2}{|c|}{ Total }} & \multirow{3}{*}{$P$ value } \\
\hline & \multicolumn{2}{|c|}{ Tidak } & \multicolumn{2}{|c|}{ Ya } & & & \\
\hline & $\mathbf{N}$ & $\%$ & $\mathbf{N}$ & $\%$ & $\mathbf{N}$ & $\%$ & \\
\hline Baik & 17 & 26,5 & 48 & 73,85 & 65 & 100 & \\
\hline Kurang Baik & 26 & 17,93 & 119 & 82,07 & 145 & 100 & 0,23 \\
\hline
\end{tabular}

Berdasarkan hasil dari

tabel 4, maka dapat diketahui

bahwa responden yang memiliki

pengetahuan tentang Tuberkulosis

Paru yang kurang baik lebih

banyak yang mengalami kejadian

tuberkulosis paru sebesar 119

responden $(82,07 \%)$ dibanding

dengan yang tidak mengalami

kejadian tuberkulosis paru sebesar

26 responden $(17,93 \%)$.
Berdasarkan

hasil

perhitungan dengan menggunakan uji Chi-Square, nilai $\mathrm{p}=0.23$. Hal ini berarti $p$-value lebih besar dari $\alpha=0.05$, sehingga dapat disimpulkan bahwa tidak ada hubungan yang bermakna antara pengetahuan tentang tuberkulosis paru dengan kejadian tuberkulosis paru pada responden $(\mathrm{p}$ value $=$ $0.23>0,05)$. 


\section{b. Hubungan Sikap mengenai}

pencegahan tuberkulosis paru

dengan Kejadian Tuberkulosis

Paru

Berdasarkan uji statistik, didapatkan hasil pada tabel sebagai berikut

Tabel 4. Hubungan Sikap mengenai pencegahan tuberkulosis paru dengan Kejadian Tuberkulosis Paru

\begin{tabular}{|c|c|c|c|c|c|c|c|c|}
\hline \multirow{3}{*}{$\begin{array}{c}\text { Sikap mengenai } \\
\text { pencegahan } \\
\text { tuberkulosis paru }\end{array}$} & \multicolumn{4}{|c|}{ Kejadian Tuberkulosis Paru } & \multirow{2}{*}{\multicolumn{2}{|c|}{ Total }} & \multirow{3}{*}{$\begin{array}{c}P \\
\text { value }\end{array}$} & \multirow{3}{*}{ OR } \\
\hline & \multicolumn{2}{|c|}{ Tidak } & \multicolumn{2}{|c|}{ Ya } & & & & \\
\hline & $\mathbf{N}$ & $\%$ & $\mathbf{N}$ & $\%$ & $\mathbf{N}$ & $\%$ & & \\
\hline Baik & 35 & 26,72 & 96 & 73,28 & 131 & 100 & & 3.237 \\
\hline Kurang Baik & 8 & 10,13 & 71 & 89,87 & 79 & 100 & 0,0001 & 3,231 \\
\hline
\end{tabular}

Berdasarkan hasil dari

tabel 5, maka dapat diketahui bahwa responden yang memiliki Sikap mengenai pencegahan tuberkulosis paru yang kurang baik lebih banyak yang mengalami kejadian tuberkulosis paru sebesar 71 responden $(89,87 \%)$ dibanding dengan yang tidak mengalami kejadian tuberkulosis paru sebesar 8 responden $(10,13 \%)$.

\section{DISKUSI}

\section{Hubungan Pengetahuan tentang Rokok}

\section{dengan Perilaku Merokok Pada Remaja}

Pengetahuan merupakan hasil tahu dan ini terjadi setelah orang melakukan penginderaan terhadap suatu obyek tertentu. Pengetahuan atau kognitif merupakan domain yang sangat penting untuk terbentuknya tindakan seseorang (Notoadmodjo, 2003). Penginderaan terjadi melalui panca indera manusia, yakni indera penglihatan, pendengaran, penciuman, rasa dan raba. Sebagian besar 
pengetahuan manusia diperoleh melalui mata dan telinga. Pengetahuan kesehatan adalah apa yang diketahui seseorang terhadap cara-cara memelihara kesehatan meliputi, pengetahuan tentang penyai menular dan tidak menular. Pengetahuan merupakan domain yang sangat penting untuk terbentuknya perilaku terbuka (overt behaviour). Perilaku yang didasari Pengetahuan umum nya bertahan lama.

Berdasarkan hasil analisis univariat, dapat diketahui bahwa responden yang memiliki pengetahuan tentang Tuberkulosis Paru yang kurang baik lebih banyak yang mengalami kejadian tuberkulosis paru sebesar 119 responden $(82,07 \%)$ dibanding dengan yang tidak mengalami kejadian tuberkulosis paru sebesar 26 responden $(17,93 \%)$. Berdasarkan hasil analisis bivariat dengan menggunakan uji ChiSquare, nilai $\mathrm{p}=0.23$. Hal ini berarti $p$ value lebih besar dari $\alpha=0.05$, sehingga dapat disimpulkan bahwa tidak ada hubungan yang bermakna antara pengetahuan tentang tuberkulosis paru dengan kejadian tuberkulosis paru pada responden $(\mathrm{p}$ value $=0.23>0,05)$.

Penelitian ini tidak sejalan dengan penelitian Dengan judul. ... Sebab, pengetahuan seseorang akan mempengaruhi kesehatan seseorang, sehingga dengan pengetahuan yang cukup maka seseorang tersebut akan berusaha berprilaku hidup bersih dan sehat. Begitu juga dengan penderitan Tuberkulosis (TBC) Paru. Setelah mengetahui mengenai penyakitnya, maka akan mengetahui tujuan dari pengobatan, pencegahan penularan, dan sebagainya.

Pengetahuan penderita yang baik tentang penyakit Tuberkulosis(TBC) paru dan pengobatannya akan meningkatkan keteraturan penderita, dibandingkan dengan penderita yang kurang akan pengetahuan penyakit Tuberkulosis (TBC) paru dan pengobatannya. Karena itu bimbingan dan pengawasan yang dilakukan oleh PMO akan lebih terarah dan baik. Sehingga akan meningkatkan keteraturan penderita dalam pengobatan tersebut sehingga angka penularan akan menurun. Seseorang yang punya pengetahuan yang baik tentang penularan Tuberkulois paru (TBC), akan berupaya untuk mencegah penularannya.

Hubungan Sikap mengenai pencegahan tuberkulosis paru dengan Kejadian Tuberkulosis Paru

Sikap merupakan reaksi atau respons seseorang yang masih tertutup terhadap suatu stimulus atau objek. Dari batasan-batasan yang ada bahwa manefistasi sikap itu ditafsirkan terlebih dahulu dari perilaku yang tertutup. Pencegahan adalah upaya secara sengaja 
di lakukan untuk mencegah terjadinya gangguan, kerusakan, atau kerugian bagi seseorang atau masyarakat.

Berdasarkan hasil analisis univariat, maka dapat diketahui bahwa responden yang memiliki Sikap mengenai pencegahan tuberkulosis paru yang kurang baik lebih banyak yang mengalami kejadian tuberkulosis paru sebesar 71 responden $(89,87 \%)$ dibanding dengan yang tidak mengalami kejadian tuberkulosis paru sebesar 8 responden $(10,13 \%)$.

Berdasarkan hasil perhitungan dengan menggunakan hasil uji ChiSquare, nilai $\mathrm{p}=0,000$. Hal ini berarti $\mathrm{p}$ value $<0.05$, sehingga dapat disimpulkan

\section{SIMPULAN}

Berdasarkan penelitian ini diketahui bahwa responden yang memiliki pengetahuan tentang Tuberkulosis Paru yang kurang baik lebih banyak yang mengalami kejadian tuberkulosis paru sebesar 119 responden $(82,07 \%)$ dan responden yang memiliki Sikap mengenai pencegahan tuberkulosis paru yang kurang baik lebih banyak yang mengalami kejadian tuberkulosis paru sebesar 71 responden $(89,87 \%)$. Berdasarkan hasil analisis bivariat dengan menggunakan uji Chi-Square, diperoleh simpulan bahwa bahwa ada hubungan yang bermakna antara sikap dengan kejadian tuberkulosis paru ( $\mathrm{p}$ value $=0,000<0,05)$, dengan $\mathrm{OR}$ sebesar 3,237. Artinya, sikap mengenai pencegahan tuberkulosis paru yang kurang baik akan meningkatkan risiko terjadinya kejadian tuberkulosis paru sebesar 3x lipat dibandingkan dengan sikap mengenai pencegahan tuberkulosis paru yang baik. Pengetahuan penderita Tuberkulosis (TBC) Paru yang kurang akan cara penularan, bahaya, dan cara pengobatan akan berpengaruh terhadap sikap dan perilaku sebagai seorang yang sakit dan akhirnya berakibat menjadi sumber penular bagi orang disekelilingnya

tidak ada hubungan yang bermakna antara pengetahuan tentang tuberkulosis paru dengan kejadian tuberkulosis paru pada responden $(\mathrm{p}$ value $=0.23>0,05)$ dan ada hubungan yang bermakna antara sikap dengan kejadian tuberkulosis paru (p value $=0,000<0,05)$, dengan OR sebesar 3,237. Artinya, sikap mengenai pencegahan tuberkulosis paru yang kurang baik akan meningkatkan risiko terjadinya kejadian tuberkulosis paru sebesar $3 \mathrm{x}$ lipat dibandingkan dengan sikap mengenai pencegahan tuberkulosis paru yang baik. 


\section{DAFTAR PUSTAKA}

Andareto, Obi. 2015. Penyakit Menular Disekitar Anda. Jakarta: Pustaka Ilmu Semesta.

Arikunto, Suharsini. 2013. Prosedur Penelitian Suatu Pendekatan Praktek. Jakarta: Rineka Cipta.

Astuti, Sumiyati. 2013. Hubungan Tingkat Penetahuan Dan Sikap Masyarakat Terhadap Upaya Pencegahan Penyakit Tubekulosis Di RW 04 Kelurahan Legoa Jakarta Utara Tahun 2013.

Azhar, Khadijah dan Dian Perwitasari. 2013. Kondisi Fisik Rumah Dan Perilaku Dengan Prevalensi Tb Paru di Provinsi DKI Jakarta, Banten, Dan Sulawesi Utara.

Citra, Muri. Dewi. 2015. Gambaran Keberhasilan Pengobatan Pada Pasien Tuberkulosis Paru BTA (+) Di Wilayah Kecamatan Ciputat, Kota Tangerang Selatan Tahun 2015.

Danusantoso, Halim. 2016. Buku Saku Ilmu Penyakit Paru. Jakarta: ECG.

Febriansyah, Rizki. 2017. Hubungan Tingkat Pengethuan Keluarga dengan Upaya Pencegahan Penularan Tuberkulosis Paru pada Keluarga di Wilayah Puskesmas Nguler, Sukuharjo.
Iswandi. 2009. Aplikasi Rapid Survey. Available at URL: http://djoko.nugroho.undip.ac.id/fil es/2009/II/lectureI.pdf. Diakses pada tanggal 05 Oktober 2017.

Marni. 2014. Asuhan Keperawatan Pada Anak Sakit Dengan Gangguan Pernafasan. Yogyakarta: Gosyen Publishing.

Masriadi. 2007. Mengenal, Mencegah, Menanggulangi TBC Paru, Ektra Paru Anak, dan pada Kehamilan. Jakarta: Yayasan Obor.

Notoadmodjo. Soekidjo. 2011. Kesehatan Masyarakat Ilmu dan Seni. Jakarta: Rineka Cipta.

Notoadmodjo. Soekijo. 2013. Promosi Kesehatan Teori dan Aplikasinya. Jakarta: Rineka Cipta. 2012. Metedologi Penelitian Kesehatan. Jakarta: Rineka Cipta

Romlah, Laila. 2015. Hubungan Merokok Dengan Kejadian Penyakit Tuberkulosis Paru di Wilayah Kerja Puskesmas Setu, Kota Tangerang Selatan. Jurnal.

Tim Program TB. St. Carolus. 2017. Tubekulosis Bisa Disembuhkan. Jakarta: KPG (Kepustakaan Populer Gramedia). 